\title{
Effects of Watercress Oil on the Thermal and Chemical Burn Injuries in Rabbits
}

\author{
Osama A. Abu-Zinadah, PhD \\ Department of Biological Sciences, Faculty of Science \\ King Abdulaziz University, Jeddah, Saudi Arabia \\ oaboznada@kau.edu.sa
}

\begin{abstract}
This study was conducted to reveal the effect of watercress oil on skin burns in rabbits. Twenty-four male rabbits were used in this study and divided into eight groups. Four groups were burned by concentrated hydrochloric acid and the others by a hot glass rod $\left(80^{\circ} \mathrm{C}\right)$ for three times. These groups were divided into two controls: two treated by the antibiotic Baneocin (Bacitracin zinc 250 IU and Neomycin 5000 IU); two treated by watercress oil and two treated by watercress and Nigella sativa oils, 1:1). The epithilialization, the contracting ability of wounds, the closure time and the time necessary for hair to grow were recorded in all groups. A histological examination was processed to test the peripheries of wounds; their thickness, their growth, the hair follicle repairing and the inflammatory cell response. Watercress acted as antimicrobial, anti-inflammatory and initiated the epithelialization from the peripheries of the wounds. The contracting ability and closure time in both antibiotic and watercress groups were significantly different from those of controls. It was concluded that watercress oil could be an effective therapy in healing skin burns in rabbits, whatever the cause of the burn may be. However, watercress oil and Nigella sativa oils (1:1) had no effect on healing these types of burns under these circumstances.
\end{abstract}

Keywords: Nigella sativa oil, Watercress oil, Burn injuries, Antibiotic Baneocin.

\section{Introduction}

Plant extracts have been widely used topically for wound healing and anti-aging. Examples of these include Ginkgo biloba, Echinacea,

Correspondence \& reprint request to: Dr. Osama A. Abu-Zinadah

P.O. Box 80203, Jeddah 21589, Saudi Arabia

Accepted for publication: 30 November 2008. Received: 15 January 2008. 
Ginseng, Watercress (Nasturtium officinale), green tea, lemon, lavender, soy, prickly pear, jojoba, Apache plume, papaya, and black seed (Nigella sativa $)^{[1,2]}$.

The fresh leaves and extract of Chromolaena odorata are used as a traditional herbal treatment of burns, soft tissue wounds and skin infections in developing countries ${ }^{[3,4]}$, where it has been shown that the extract had an effect on the growth and proliferation of keratinocytes and fibroblasts in culture ${ }^{[2]}$. They also showed that the extract stimulated the expression of many proteins on the adhesion complex and fibronectin by human keratinocytes. The adhesion complex proteins are essential to stabilize epithelium $^{[4]}$.

The treatment of chronic marginal parodontopathies with natural products from plant extracts; including watercress with comparison to other drugs, including zinc chloride, showed the bactericidal activities and stress antimycotic effects of the plant extracts, especially against Candida albicans ${ }^{[5]}$. The extracts had good repair effects with no side effects which are attributed to other drugs employed ${ }^{[5]}$.

Watercress is the richest source of glucosinolates, which can be hydrolyzed to produce phenethyl isothiocyanate (PEITC). Interest in watercress is rising, since the demonstration that PEITC may have a protective effect against cancer. PEITC can increase linearly with the age of plant within 40 days $^{[6]}$. The PEITC was found to inhibit phase I enzymes, which are responsible for the activation of many carcinogens in animals and induced phase II enzymes, which are associated with enhanced excretion of carcinogens ${ }^{[7,8]}$. Isothiocyanates are released upon chewing or maceration of watercress and other cruciferous vegetables in which they occur as thioglycoside conjugates called glucosinolates ${ }^{[9]}$. The enzyme myrosinase hydrolyzes the glucosinolates producing isothiocyanates. Consumption of average portions of cruciferous vegetables can result in the release of tens milligrams of isothiocyanate ${ }^{[10,11]}$. Isothiocyanates can prevent carcinogen activation through the inhibition of phase I enzymes, such as cytochrome P 450s ${ }^{[12]}$ and through triggering phase II enzymes such as quinine reductase: (quinine - acceptor), oxidoreductase, glutathione - S - transferase and glucuronosyltransferases, resulting ultimately in the excretion of potential carcinogens ${ }^{[13,14]}$. In addition, these compounds can induce 
apoptosis via activation of the stress activated protein kinas pathway ${ }^{[15,16]}$.

The aim of this study is to evaluate the effect of watercress oil alone, and in combination with Nigella sativa oil on the process of burn healing and compare them with conventional therapy.

\section{Materials and Methods}

\section{Experimental Animals}

Twenty-four male rabbits, Oryctolagus cuniculus (Mammalia, Lagomorpha, Leporidae), with an average weight between $0.50-0.75 \mathrm{~kg}$ were housed in good conditions and fed with commercial foods (crushed wheat and corn). The rabbits were housed in cages and were given $150 \mathrm{~g}$ commercial food of Lab Rabbit Chow HF 5326 per day. After induction of burns, the animals were housed separately to avoid contact and contamination. Twenty-four animals were divided into 8 groups (Table 1); two controls; two for treatment with antibiotic; two for treatment with watercress oil and two for treatment with watercress and Nigella sativa oils $(1: 1)$.

Table 1. Experimental design.

\begin{tabular}{c|c|c|c|c}
\hline \multicolumn{5}{c}{ Number of animals (24) } \\
\hline $\begin{array}{c}\text { Mixed oils } \\
\text { Treated group }\end{array}$ & $\begin{array}{c}\text { Watercress oil } \\
\text { Treated group }\end{array}$ & $\begin{array}{c}\text { Antibiotic } \\
\text { Treated group }\end{array}$ & $\begin{array}{c}\text { Control } \\
\text { Untreated group }\end{array}$ & $\begin{array}{c}\text { Type of } \\
\text { burn }\end{array}$ \\
\hline 3 animals & 3 animals & 3 animals & 3 animals & Acid \\
\hline 3 animals & 3 animals & 3 animals & 3 animals & Heat \\
\hline
\end{tabular}

\section{Induction of Burns}

The hairs of the dorsal skin were shaved mechanically $24 \mathrm{~h}$ before burn induction. The animals were left for $24 \mathrm{~h}$ to recur any inflammation caused by the shaving. Two models of burn injuries were used: the first by inducing a chemical injury by spreading minute drops of concentrated $\mathrm{HCl}$ upon the shaved skin on $7 \times 7 \mathrm{~cm}$ area. The second by inducing thermal injury, where direct heat was applied using a hot glass rod $80^{\circ} \mathrm{C}$ on the dorsal skin for $1 \mathrm{~min}$ three times in the same areas ${ }^{[4,17]}$. The burned animals were housed separately in partitioned cages to avoid infections. 


\section{Topical Treatment of Burns}

The control groups were left without treatment. The antibiotic groups were topically treated by spreading a thin layer of Baneocin ointment (Bacitracin Zinc $250 \mathrm{IU}$ and Neomycin $5000 \mathrm{IU} / \mathrm{g}$ ) twice daily (Pharco Pharmaceuticals, Egypt). The used extract of Watercress; Nasturtium officinale (Crucifer, Nasturtium) was purchased from Eva Pharmaceutical, Inc., Egypt and was spread carefully twice a day upon the burn. Watercress and Nigella sativa oils $(1: 1 \mathrm{v} / \mathrm{v})$ were spread topically upon the burned skin twice a day.

\section{Macroscopic Measurements}

Visual examination: the periphery, epithelial structure, contamination, closure time, contracting ability and growing hair time were observed and recorded.

The peripheries of burns were observed: the erythema, thickness, inflammation and the contamination of burns were recorded; the closure time was estimated through the daily measurements of the size of the burns. The contracting ability was estimated according to the repairing of wound to the normal skin architecture through topical treatment of burns and the growing hair time from the first day of seeing hairs upon the repaired skin.

\section{Microscopic Observation}

One rabbit of each group was sacrificed after one, 3 and 5 wks. The burned skin was fixed in a neutral formalin solution (10\%) for $24 \mathrm{~h}$, then washed under running water for $24 \mathrm{~h}$. The skin was dehydrated in increasing concentrations of ethyl alcohol, embedded in paraffin wax, sectioned and stained by hematoxylin and eosin stains.

The significance of the tabulated values was tested by "student's" $t$ test between the treated and untreated values.

\section{Results}

\section{Contracting Ability of Burn Wounds}

The wounds of the control groups were bigger than those of the treated ones, in addition to their contamination and inflammation. 
Moreover, erythema bleeding occurred on the peripheries of the wounds. At the third week, wounds became wider with more inflammations; their peripheries became thicker and not contracted. At the end of the fifth week, the wound was covered with a hard and thick material, no hair growth in both chemically and direct heat induced types of wounds were observed (Table 2; Fig. 1 and 2).

Table 2. Testing volumes of the burned skin of rabbit, chemically and direct fire-induced after topical application of treatments till 5 weeks.

\begin{tabular}{|c|c|c|c|c|c|c|}
\hline \multirow{2}{*}{$\begin{array}{l}\text { Experimental } \\
\text { groups }\end{array}$} & \multirow{3}{*}{$\begin{array}{l}\text { Type of } \\
\text { burn }\end{array}$} & \multicolumn{5}{|c|}{ Mean volumes of wounds $\left(\mathrm{cm}^{2}\right) \pm S D$} \\
\hline & & \multicolumn{5}{|c|}{ Testing periods (weeks) } \\
\hline \multirow{3}{*}{ Control groups } & & 1 & 2 & 3 & 4 & 5 \\
\hline & Acid & $\begin{array}{l}7.35 \pm \\
0.45\end{array}$ & $\begin{array}{c}6.17 \pm \\
0.46\end{array}$ & $\begin{array}{c}8.36 \pm \\
0.31\end{array}$ & $\begin{array}{l}7.31 \pm \\
0.52\end{array}$ & $\begin{array}{c}5.67 \pm \\
0.19\end{array}$ \\
\hline & Fire & $\begin{array}{c}4.54 \pm \\
0.19\end{array}$ & $\begin{array}{c}4.99 \pm \\
0.25\end{array}$ & $\begin{array}{c}5.46 \\
\pm 0.30^{\dagger}\end{array}$ & $\begin{array}{c}5.43 \\
\pm 0.32^{\dagger}\end{array}$ & $\begin{array}{c}4.01 \\
\pm 0.11^{\dagger}\end{array}$ \\
\hline \multirow{2}{*}{ Antibiotic groups } & Acid & $\begin{array}{c}5.41 \pm \\
0.38\end{array}$ & $\begin{array}{c}3.98 \\
\pm 0.38\end{array}$ & $\begin{array}{c}2.21 \\
\pm 0.41^{\dagger}\end{array}$ & $\begin{array}{c}1.31 \\
\pm 0.18^{\dagger}\end{array}$ & $\begin{array}{c}0.71 \\
\pm 0.11^{\dagger}\end{array}$ \\
\hline & Fire & $\begin{array}{c}3.98 \pm \\
0.23\end{array}$ & $\begin{array}{c}3.71 \\
\pm 0.18\end{array}$ * & $\begin{array}{c}1.85 \\
\pm 0.11^{\dagger}\end{array}$ & $\begin{array}{c}1.11 \\
\pm 0.08^{\dagger}\end{array}$ & $\begin{array}{c}0.29 \\
\pm 0.06^{\dagger}\end{array}$ \\
\hline \multirow{2}{*}{$\begin{array}{l}\text { Watercress oil } \\
\text { groups }\end{array}$} & Acid & $\begin{array}{c}6.71 \pm \\
0.41\end{array}$ & $\begin{array}{c}5.13 \\
\pm 0.31\end{array}$ * & $\begin{array}{c}3.11 \\
\pm 0.27^{\dagger}\end{array}$ & $\begin{array}{c}2.09 \\
\pm 0.18^{\dagger}\end{array}$ & $\begin{array}{c}1.18 \pm \\
0.8\end{array}$ \\
\hline & Fire & $\begin{array}{c}4.97 \pm \\
0.35\end{array}$ & $\begin{array}{c}3.58 \pm \\
0.28\end{array}$ & $\begin{array}{c}2.55 \pm \\
0.28\end{array}$ & $\begin{array}{c}2.11 \pm \\
0.21\end{array}$ & $\begin{array}{c}1.13 \\
\pm 0.18^{\dagger}\end{array}$ \\
\hline \multirow{2}{*}{$\begin{array}{l}\text { Mixed Watercress } \\
\& N . \text { sativa oils }\end{array}$} & Acid & $\begin{array}{c}7.72 \pm \\
0.35\end{array}$ & $\begin{array}{l}6.72 \pm \\
0.33\end{array}$ & $\begin{array}{c}5.39 \pm \\
0.40\end{array}$ & $\begin{array}{c}4.62 \pm \\
0.26\end{array}$ & $\begin{array}{c}2.97 \\
\pm 0.12^{\dagger}\end{array}$ \\
\hline & Fire & $\begin{array}{c}4.38 \pm \\
0.22\end{array}$ & $\begin{array}{c}4.09 \pm \\
0.31\end{array}$ & $\begin{array}{c}3.22 \pm \\
0.37\end{array}$ & $\begin{array}{c}2.65 \pm \\
0.27\end{array}$ & $\begin{array}{c}1.21 \pm \\
0.11\end{array}$ \\
\hline
\end{tabular}

The recorded mean is the average mean of three values.

N.B: ${ }^{*}$ Significant $p<0.005$; ${ }^{\dagger}$ Highly Significant $p<0.005$ 


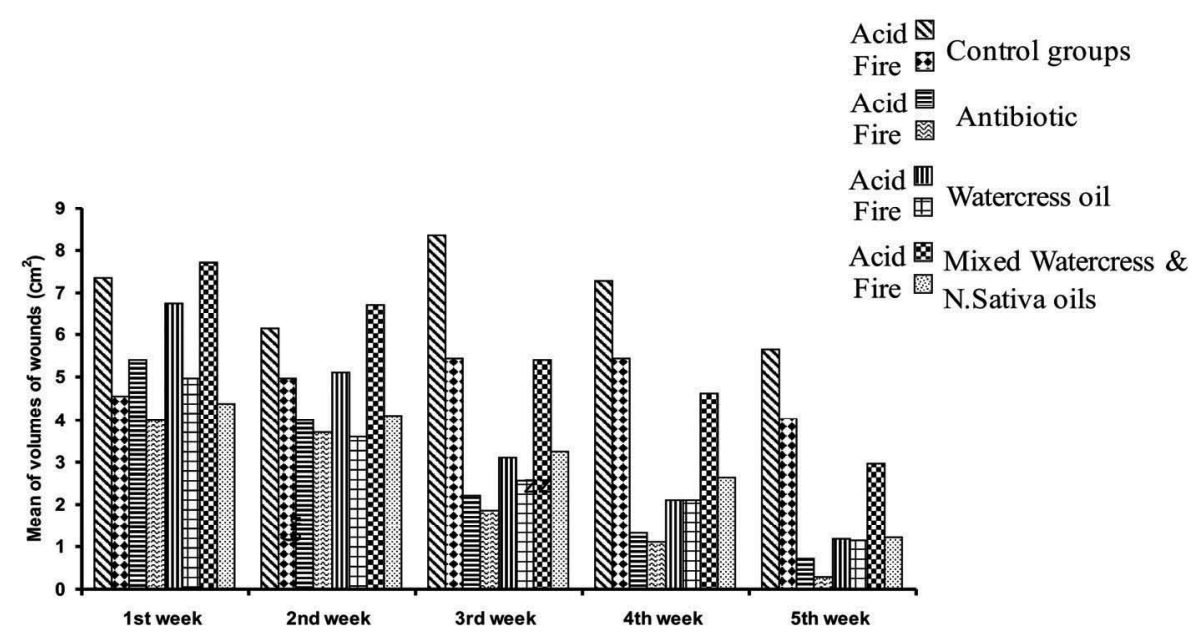

Fig. 1. Changes of wound volumes $\left(\mathrm{cm}^{2}\right)$ after topical application of treatment till 5 weeks.

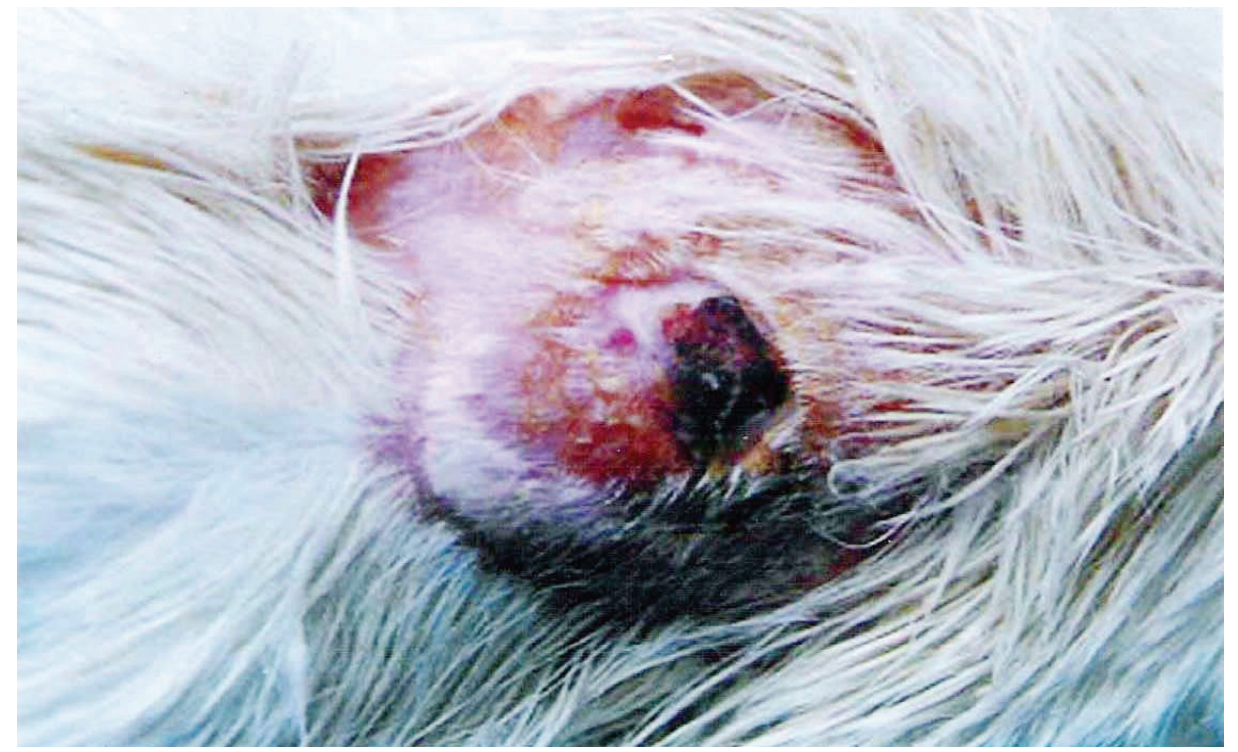

Fig. 2. Showing burned untreated skin of rabbits after topical application.

The mean areas of wound sizes in the antibiotic treated groups were contracted significantly after the first week of topical treatment with Baneocin. The closure time was found to be between Day 18 and Day 22 and the hair growth time was at the beginning of the fifth week. 
Rabbits treated with watercress oil showed the same pattern of results as rabbits treated with the antibiotic. Groups treated with the two oils mixture showed no significant changes compared to the other two groups (Fig. 1, 3-5).

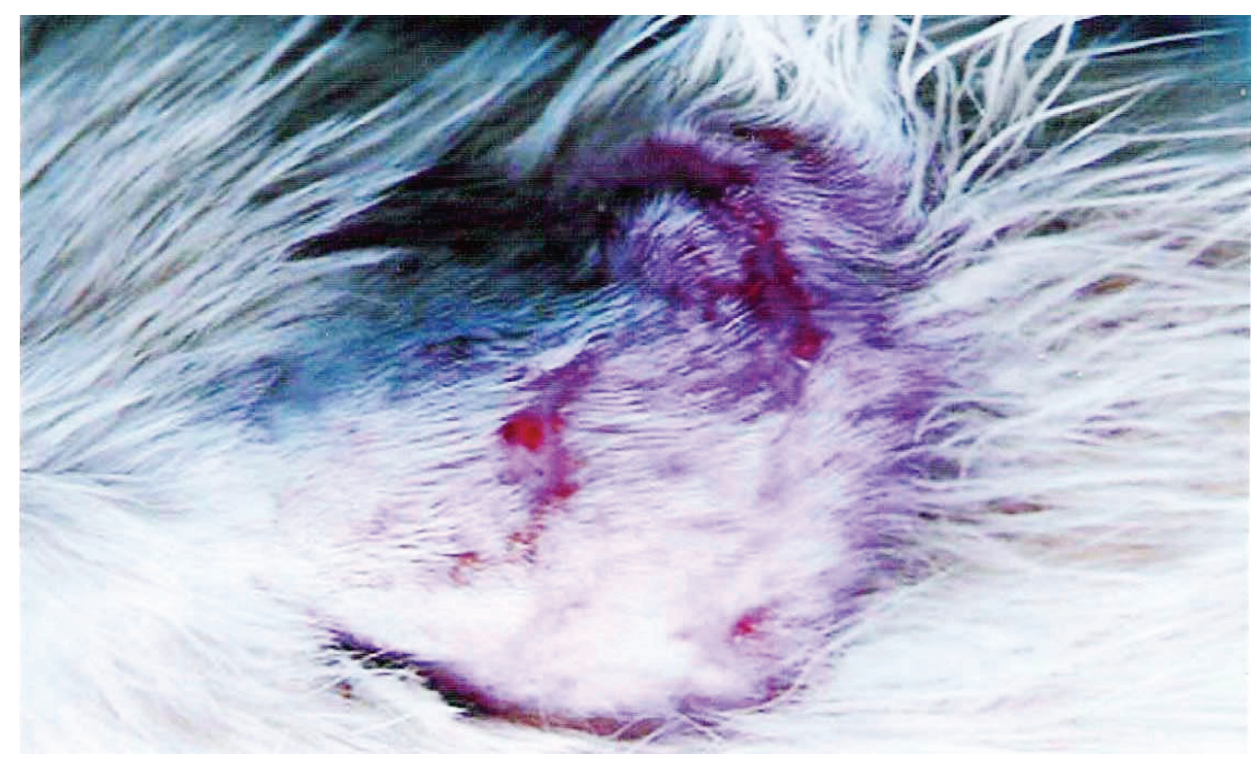

Fig. 3. Treated burned skin by Baneocin.

\section{Microscopic Observations}

The burn wounds architecture was distracted; the epidermis was severely hurt and the dermis became necrotic (Fig. 7). The hair roots and dermal glands degenerated completely. The untreated wounds were found covered by thick necrotic materials and became deeper, their peripheries with severely inflammation and hyperplasia with large number of inflammatory cells were observed. The treated wounds (chemically and heat induced) in all treated groups showed certain changes; the inflammatory cells were scattered beneath the burned skin, the peripheries were increased and gave rise to a horny layer covering the wound. The hair roots grew in the peripheries of the wounds and certain parts of glands were also repaired (Fig. 8 \& 9). The mixed oils of watercress and Nigella sativa had less effect in the repairing process (Table 2). 


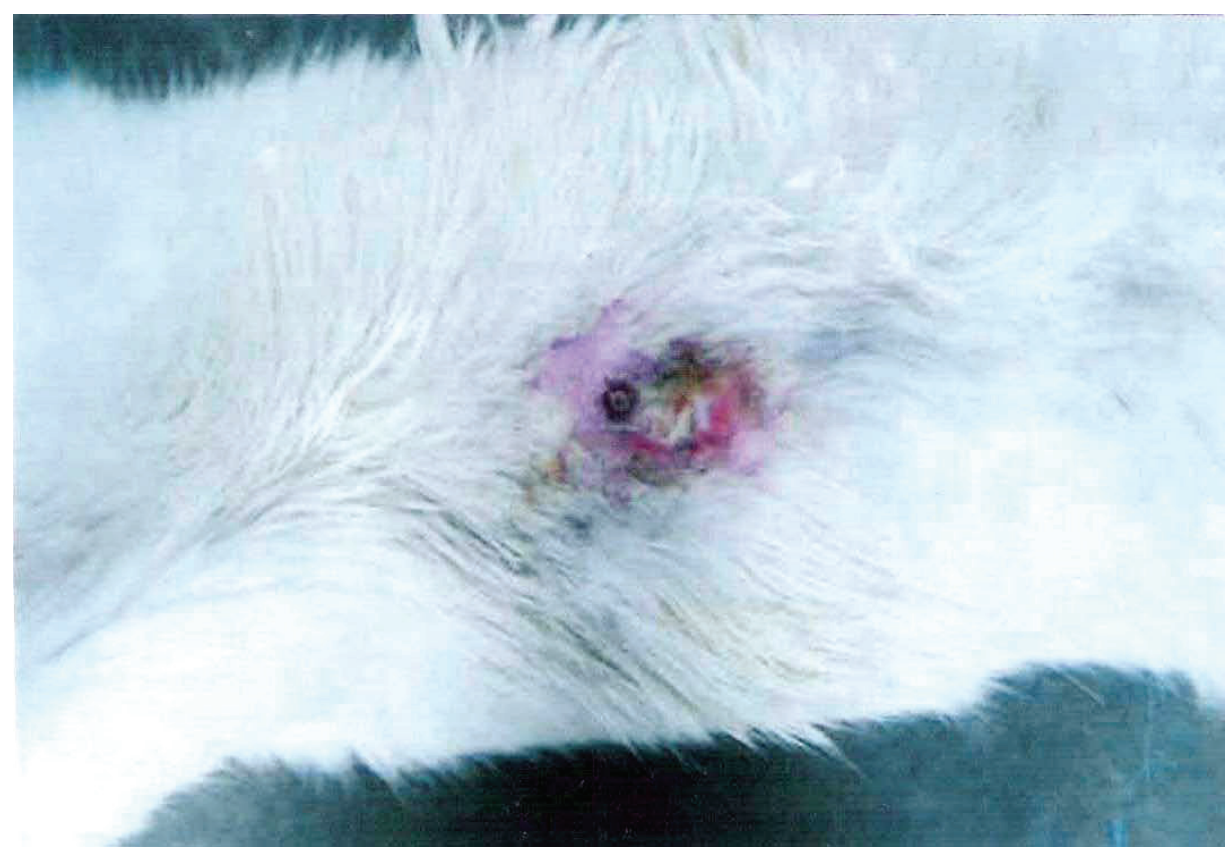

Fig. 4. Treated burned skin by watercress oil.

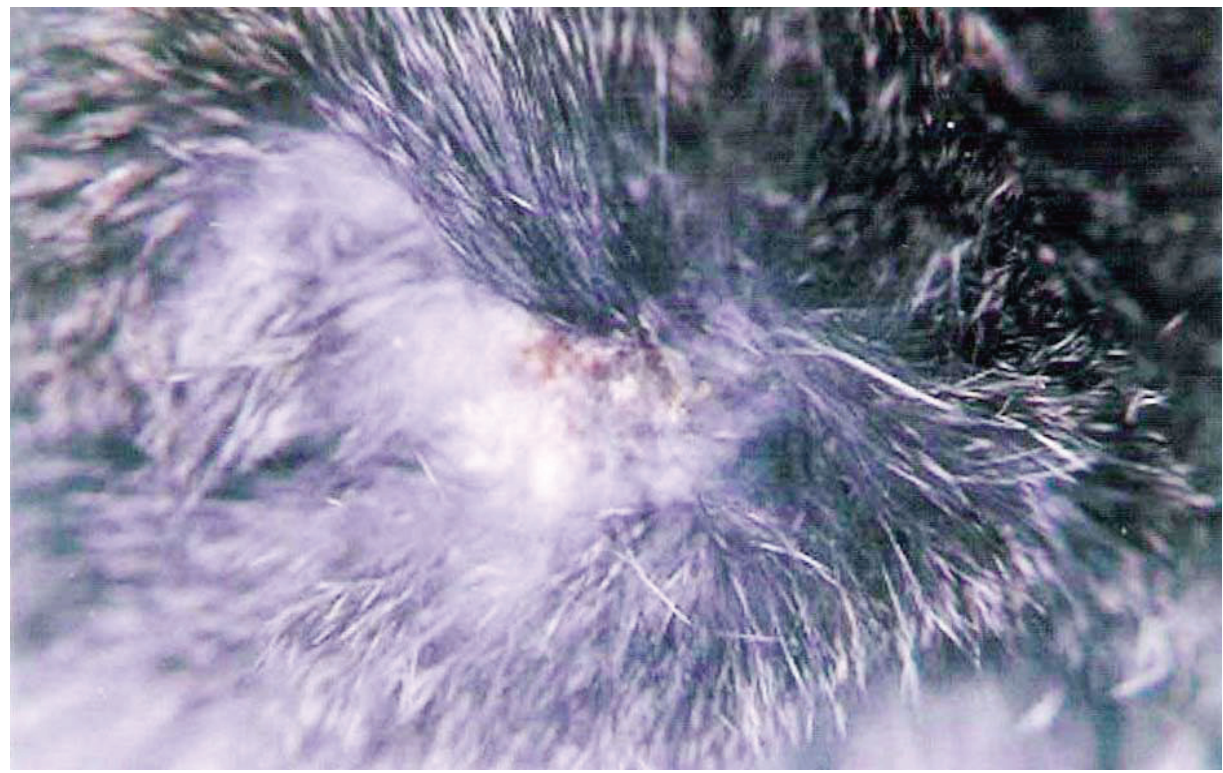

Fig. 5. Treated burned skin by mixed oils of watercress and Nigella sativa for 5 weeks. 


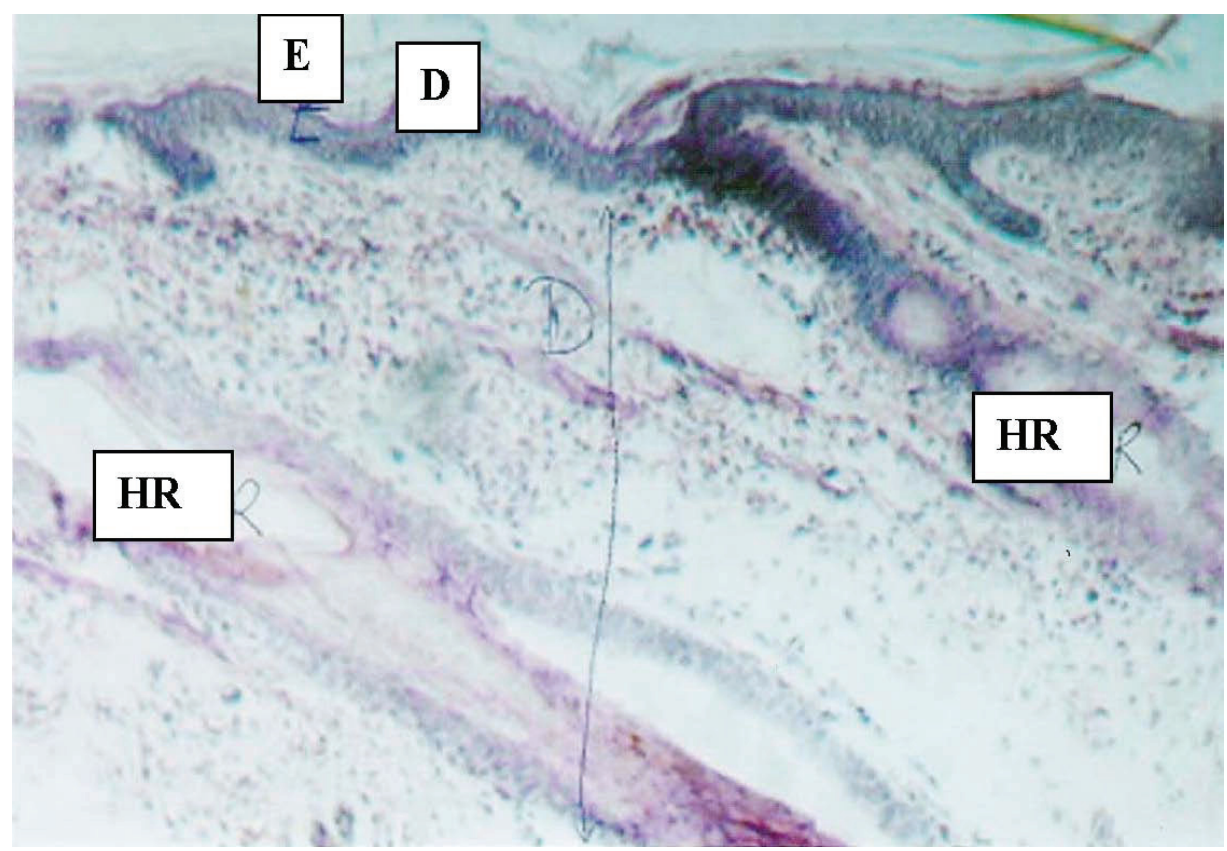

Fig. 6. V.S ob burned skin showing typical structure of epidermis (E), dermis (D) and typical (HR).

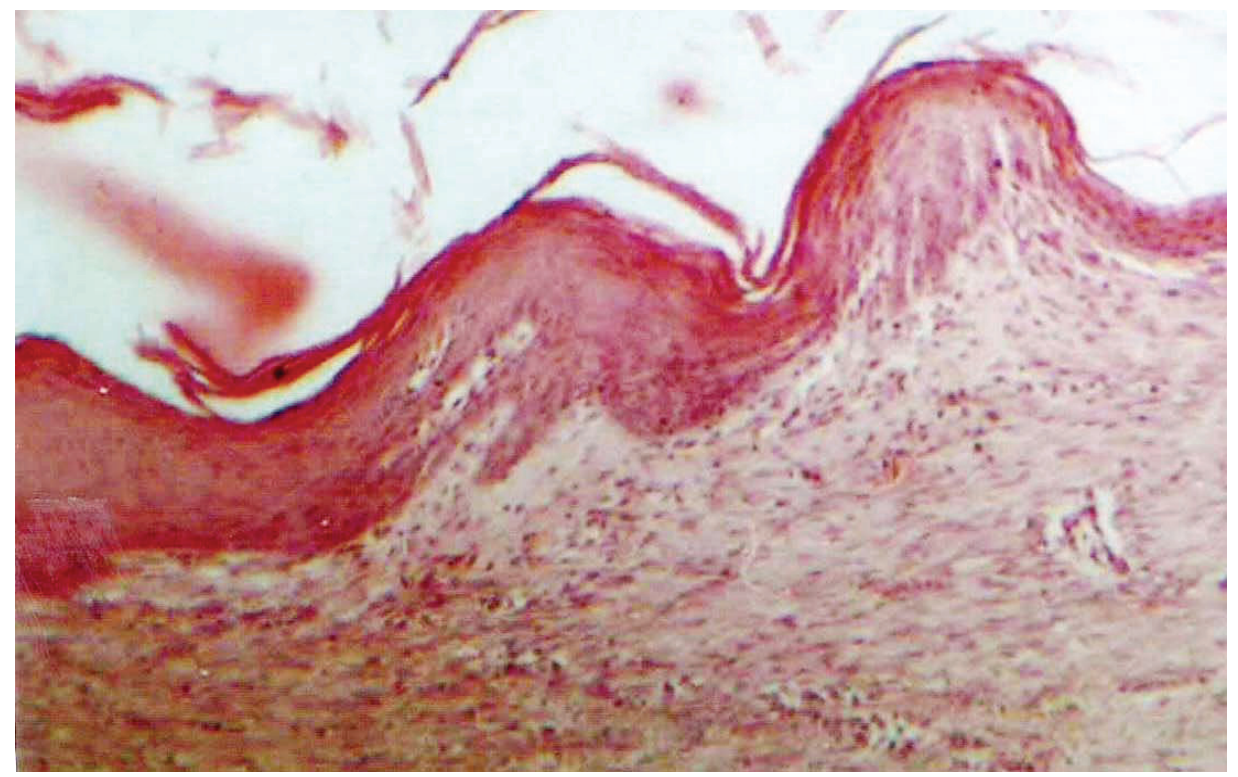

Fig. 7. V.S. of burned skin showing severely distracted epidermis. 


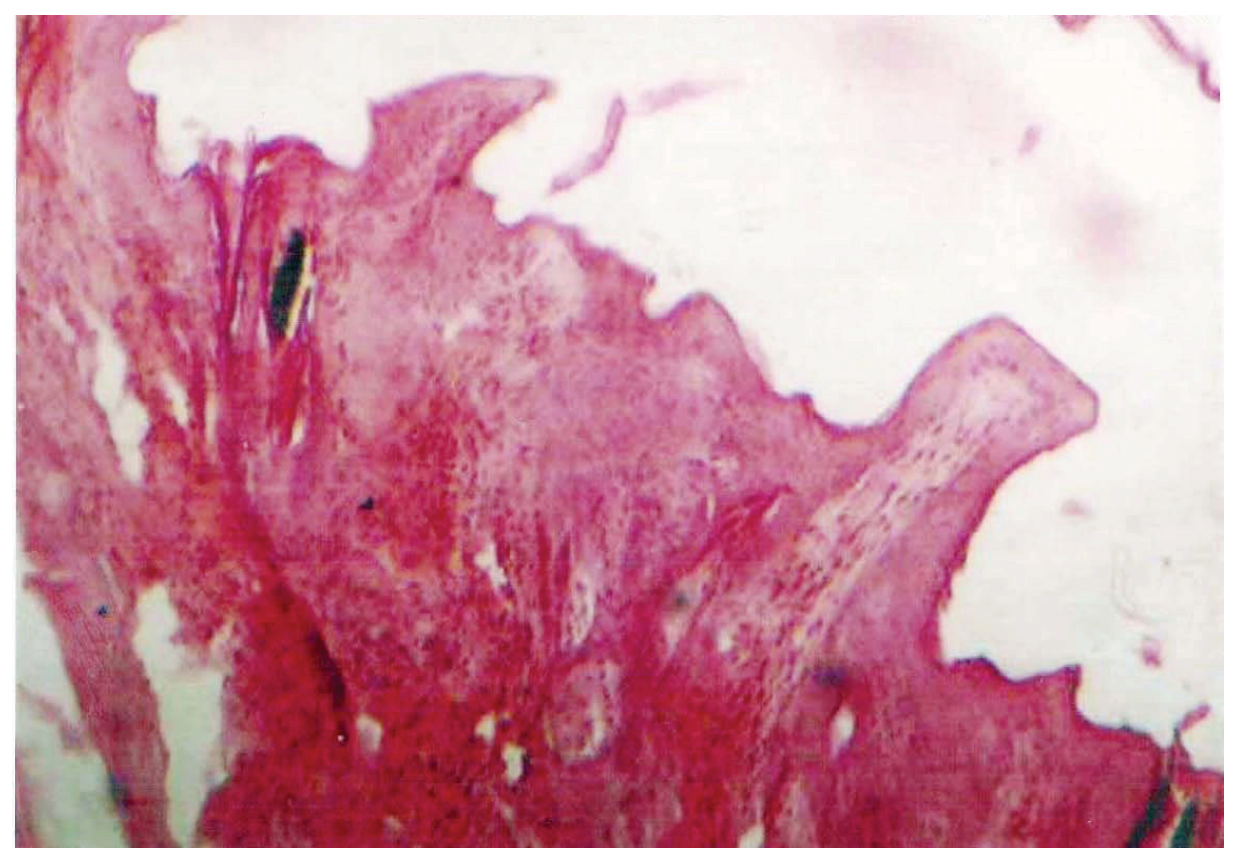

Fig. 8. V.S. of treated burned skin showing horny layer covering the wound.

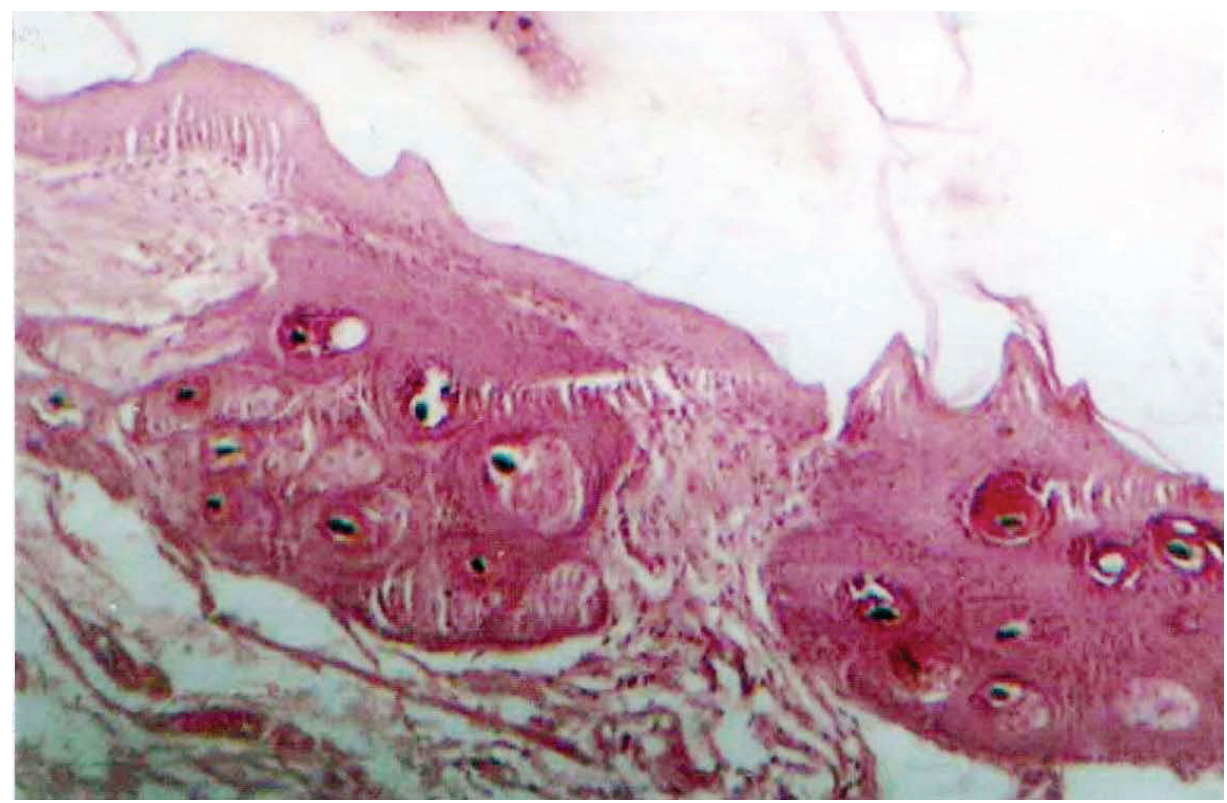

Fig. 9. V.S. of treated burned skin showing hair roots grew in the wound peripheries. 


\section{Discussion}

In the present study, watercress oil was applied to the experimental burns induced chemically and by direct heat to test its effect on epithelialization (repairing of the burned tissues), wound contraction and regeneration of the hair follicles. The results were compared with those treated by the antibiotic application (Baneocin zinc). It was found that the erythema, thickness and inflammation were severely recorded in the control groups. These observations were significantly lower in animals treated with the antibiotic as well as watercress oil. Many investigators used plants recorded in traditional medicine for sores, ulcers and skin eruption. Pyria et al. ${ }^{[17,18]}$ used Datura alba and Celosia argentea in such work to investigate the healing efficacy of these plants using a rat burn model. The extract of Celosia argentea promoted cell motility and proliferation of primarily dermal fibroblast and keratinocytes which may accelerate wound closure observed in treated groups. This may be due to mitogenic and motogemc promotion of dermal fibroblasts ${ }^{[19]}$. Campos et $a l^{[20]}$ used Asian yellow flower of the genus Ranunculus and indicated the efficacy of this plant to treat ulcers, sores, scabs and some types of burns. Campos et al. ${ }^{[21]}$ speculated that a burn is being a tissue lesion which provokes different alterations that vary from topical erythema to total destruction of the structures affected. A burn always produces an alteration in the skin; a lesion in the corneal strata is sufficient to cause the skin to lose its capacity to act as a barrier. The goal of a burn treatment is to produce epithelization as soon as possible, while the use of topical antibiotic is to prevent infections.

These results showed that the burn wounds of untreated groups were contaminated, as they were not repaired, while those of treated groups by drugs and plant oils restored the normal architecture more rapidly, and the closure time was significantly reduced between 18 and 23 days. Su et $a l .{ }^{[22]}$ investigated the effect of a plant mixture in a liquid, which is known as (burn healing liquid) on the proliferation of keratinocytes and fibroblasts to explore the potential effect of this liquid on the contraction of burns wounds. It was found that the burn healing liquid enhanced the growth of keratinocytes and fibroblasts.

A New Zealand white rabbit's skin was soaked in multi - peptides of Tripterygium wilfordii, dexamethasone and normal saline. This skin possessed partial compatibility with recipient after the skin was 
pretreated $^{[23]}$. The widely used plant extracts for wound healing share a common character: they may contain flavonoid compounds with phenolic groups. These phytochemicals are highly reactive with other compounds, such as reactive oxygen species and biological micro molecules to scavenge free radicals or initiate biological effects ${ }^{[24]}$. One of the most obvious reasons, which benefit watercress oil in healing burned wounds, is the antimicrobial activities of (PEITC) phytochemical substances which kill microbes or neutralize free radicals and initiate biological actions. Hirasawa et al. ${ }^{[25]}$ used the extract of Pseudolarix amabilis for in vitro antibacterial, anti-inflammatory, and inhibitory effect of histamine. It also examined the efficacy on dermatitis in mice and found that the extract inhibited both, proliferation of bacteria and inflammation caused by antigen.

In contrast, peripheral blood mononuclear lymphocytes from thermally injured patients, were examined for their ability to mediate spontaneous natural demise and cytotoxic activity using the fluorescein isothiocyanate conjugated monoclonal antibody. The inability of thermal injury patients to mediate normal natural killer cell function may contribute to their susceptibilities of viral infection ${ }^{[26]}$.

The beneficial aspects of medicinal plants on skin include: healing of wounds and burn injuries, antifungal antiviral, antibacterial, acaricide activity against skin infection such as herpes, activity against inflammatory/immune disorder and antitumor promoting activity against skin cancer ${ }^{[1,27]}$. However, Hansbrough et al. ${ }^{[28]}$ studied the phenotypic and functional characteristic of murine and human cell after burn injury, and revealed characteristic changes including the presence of activated suppressor cells during post-injury suppression. In a study designed to determine the possible protective effect of the extract of Ginkgo biloba against oxidative organ damage distant from the original burn wound. This oxidative stress was protected by administration of the plant extract. Therefore, its therapeutic role as a tissue injury-limiting agent must be further elucidated in oxidant induced tissue damage ${ }^{[29,30]}$.

This study's results indicated the beneficial use of watercress oil on healing the partial thickness burn wounds. Such an effect was similar to Baneocin drug. The same results were obtained by the application of the Brazilian propolis skin cream for antimicrobial and anti-inflammatory properties, and compared with silver sulfadiazine in the treatment of 
minor burns ${ }^{[31]}$. The antimicrobial activity was also studied by Feresin et $a l .{ }^{[32]}$ who used the Argentinean medicinal plant (Baccharis grisebachii) and speculated that this plant was used to treat ulcers, burns and skin sores, and showed activity towards dermatophytes and bacteria.

\section{Conclusion}

Watercress oil could be an effective therapy in healing skin burns in rabbits, whatever the cause of the burn. However, watercress oil mixed with Nigella sativa oil had no significant effect in healing these types of burn wounds under these circumstances.

\section{References}

[1] Mantle D, Gok MA, Lennard TW, Adverse and beneficial effects of plant extracts on skin and skin disorders, Adverse Drug React Toxicol Rev, 2001; 20(2): 89-103.

[2] Foster S, Duk JA, Watercress in Medical Plants, Houghton Miffin Co, New York: Academic P, 2006.

[3] Phan TT, Allen J, Hughes MA, Cherry G, Wojnarowska F, Upregulation of adhesion complex proteins and fibronectin by human keratinocytes treated with an aqueous extract from the leaves of Chromolaena odorata (Eupolin), Eur J Dermatol, 2000; 10(7): 522-526.

[4] Louise F, New organic skin care recipes to treat various burned animals naturally, Online $J$. Amazon. Com, MLM.Com., 2007; 247(2).

[5] Gafar M, Dumitriu H, Dumitriu S, Guti L, [Apiphytotherapeutic original preparations in the treatment of chronic marginal parodontopathies. A clinical and microbiological study] Rev Chir Oncol Radiol O R L Oftalmol Stomatol Ser Stomatol, 1989; 36(2): 91-98.

[6] Palaniswamy UR, McAvoy RJ, Bible BB, Stuart JD, Ontogenic variations of ascorbic acid and phenethyl isothiocyanate concentrations in watercress (Nasturtium oofficinale R.Br.) leaves, J Agric Food Chem, 2003; 51(18): 5504-5509.

[7] Rose P, Faulkner K, Williamson G, Mithen R, 7-Methylsulfinylheptyl and 8methylsulfinyloctyl isothiocyanates from watercress are potent inducers of phase II enzymes, Carcinogenesis, 2000; 21(11): 1983-1988.

[8] Hecht SS, Shiny FL, Effects of watercress consumption on metabolism, Epidemol Biomarkers Rev, 2007; 428; 877-884.

[9] Tookey HL, Van Etten CH, Daxenbichler, ME, Glucosinolates. In: Toxic constituents of Plant Stuffs. Liner IE., eds. New York: Academic P, 1980. 103-142

[10] Chung FL, Morse MA, Eklind KI, Lewis J, Quantitation of human uptake of the anticarcinogen phenethyl isothiocyanate after a watercress meal, Cancer Epidemiol Biomarkers Pev, 1992; 1(5): 383-388.

[11] Hecht SS, Chung FL, Richie JP, Akerkar SA, Borukhova A, Skowronski L, Carmella SG, Effect of watercress consumption on metabolism of a tobacco-specific lung carcinogen in smokers, Cancer Epidemiol Biomarkers Pev, 1995; 4(8): 877-884.

[12] Conaway CC, Jiao D, Chung FL, Inhibition of rat liver cytochrome P450 isozymes by isothiocyanate and their conjugates: a structure activity relationship study, Carcinogenesis, 1996; 17(11): 2423-2427.

[13] Zhang Y, Kensler TW, Cho CG, Posner GH, Talalay P, Induction of rat pancreatic glutathione - S - transferase and quinone reductase activities by a mixture of glucosinolate break down derivatives found in Brussel sprouts, Food Chem Toxicol, 1994; 36: 365-373. 
[14] Bianchet MA, Foster C, Faig M, Talalay P, Amzel LM, Structure and mechanism of cytosolic quinone reductases, Biochem Soc Trans, 1999; 27(4): 610-615.

[15] Chen YR, Wang W, Kong AN, Tan TH, Molecular mechanisms of c-Jun N-terminal kinase-mediated apoptosis induced by anticarcinogenic isothiocyanates, $\mathrm{J} \mathrm{Biol} \mathrm{Chem,} \mathrm{1998;}$ 273(3): 1769-1775.

[16] Huang CS, Ma WY, Li J, Hecht SS, Dong Z, Essential role of p53 in phenylethyl isothiocyanate-induced apoptosis, Cancer Res, 1998; 58(18): 4102-4106.

[17] Priya KS, Gnanamani A, Radhakrishnan N, Babu M, Healing potential of Datura alba on burn wounds in albino rats, J Ethnopharmacol, 2002; 83(3): 193-199.

[18] Priya KS, Arumugam G, Rathinam B, Wells A, Babu M, Celosia argentea Linn, leaf extract improves wound healing in a rat burn wound model, Wound Repair Regen, 2004; 12(6): 618-625.

[19] Hu J, Ren L, [Experimental study of the effect of danshen on the viability of burned skin] Zhongguo Xiu Fu Chong Jian Wai Ke Za Zhi, 1998; 12(4): 205-208.

[20] Salas Campos L, Fernándes Mansilla M, Martínez de la Chica AM, [Topical chemotherapy for treatment of burns] Rev Enferm, 2005; 28(5): 67-70.

[21] Salas Campos L, Pastor Amorós T, Martín Campos R, Martínez de la Chica A, De Haro Barrios A, [Therapeutic uses for Asian yellow - flowered crowfoot, genus Ranunculus: the case of Blastoestimulina] Rev Enferm, 2005; 28(1): 59-62.

[22] Su Y, Chen B, Thang PT, Hughes MA Xu X, Cherry GW, Effect of burn healing liquid on keratinocyte and fibroblast proliferation and on collagen lattice contraction, Chin Med $J$ (Engl), 1999; 112(8): 720-727.

[23] You G, Liang L, Zheng L, Luo X, Li J, Qiu J, [An observation of repair of burn wound with consanguineous skin pretreated with Tripterygium wilfordii] Zhonghua Shao Shang Za Zhi, 2002; 18(6): 372-374.

[24] Hsu S, Green tea and skin, J Am Acad Dermatol, 2005; 52(6): 1049-1059.

[25] Hirasawa Y, Ori K, Yamada T, Ohtsu S, Matsui Y, Miwa Y, Iwasaki S, Shimizu M, Kyuki K, Higo S, [Anti-allergic action effect of Pseudolarix amabilis Rehd. extract and its efficacy on atopic dermatitis] Nippon Yakurigaku Zasshi, 2004; 124(4): 271-283.

[26] Stein MD, Gamble DN, Klimpel KD, Herndon DN, Klimpel GR, Natural killer cell defects resulting from thermal injury, Cell Immunol, 1984; 86(2): 551-556.

[27] [No authors listed], Watercress 'targets' cancer. UK: Medicinal Herbs Company, 2007. $<$ http://www.inthenews.co.uk/news/health/watercress-targets-cancer-\$465996.htm>

[28] Hansbrough JF, Field TO Jr, Gadd MA, Soderberg C, Immune response modulation after burn injury: T cells and antibodies, J Burn Care Rehabil, 1987; 8(6): 509-512.

[29] Sakarcan A, Sehirli O, Velioglu-Ovünç A, Ercan F, Erkanl G, Gedik N, Sener G, Ginkgo biloba extract improves oxidative organ damage in a rat model of thermal trauma, $J$ Burn Care Rehabil, 2005; 26(6): 515-524.

[30] Bate, A, Botanical Anti-Aging Skin Care Ingredient Guide; Watercress Extract, Houghton Miffin Company, New York: Academic P, 2007.

[31] Gregory SR, Piccolo N, Piccolo MT, Piccolo MS, Heggers JP, Comparison of propolis skin cream to silver sulfadiazine: a naturopathic alternative to antibiotics in treatment of minor burns, $J$ Altern Complement Med, 2002; 8(1): 77-83.

[32] Feresin GE, Tapia A, Gimenez A, Ravelo AG, Zacchino S, Sortino M, SchmedaHirschmann G, Constituents of the Argentinian medicinal plant Baccharis grisebachii and their antimicrobial activity, $J$ Ethnopharmacol, 2003; 89(1): 73-80. 


\section{القيمة العلاجية لزيت الجرجير في علاج أضرار الحروق الكيماوية و الحر ارية المختلفة فى الأر انب}

\section{أسامة عبدالله أبو زنادة}

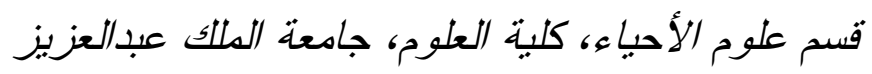

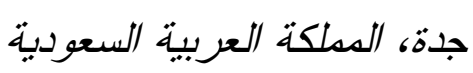

الستخلص. كان من أهم أهداف هذا العمل هو علاج أضرار الحروق

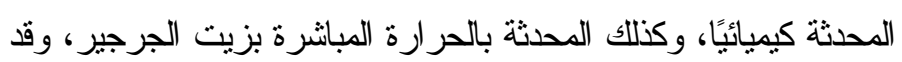

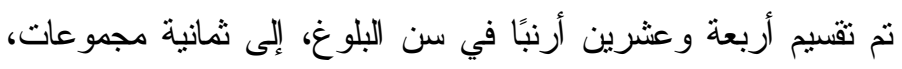

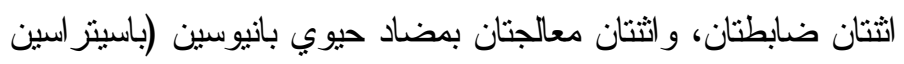

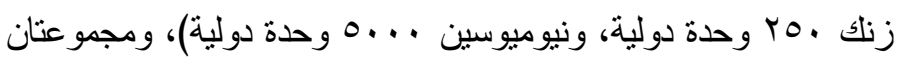

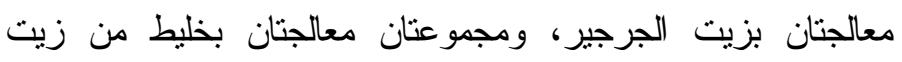

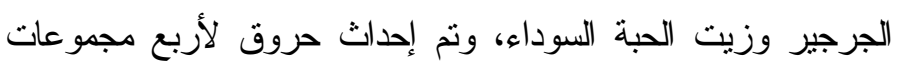

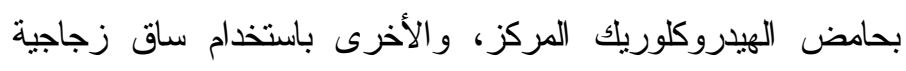

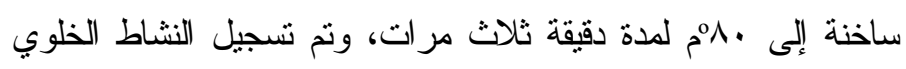

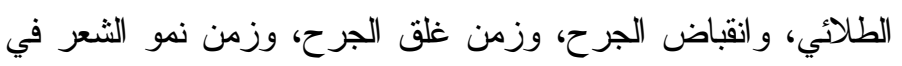

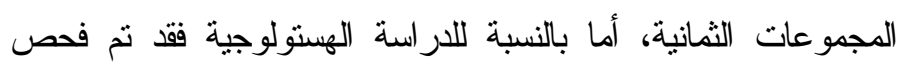

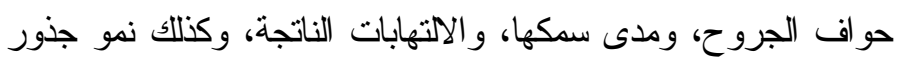

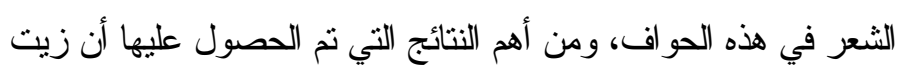

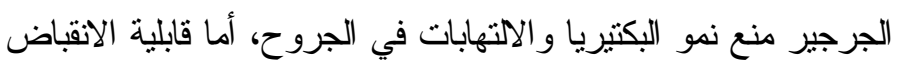

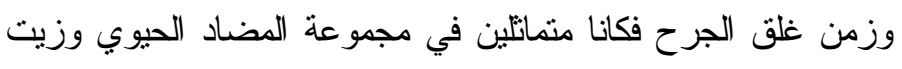

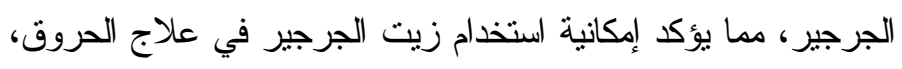

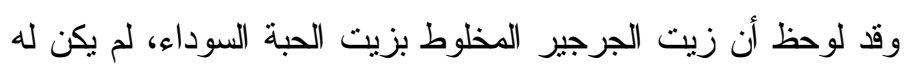

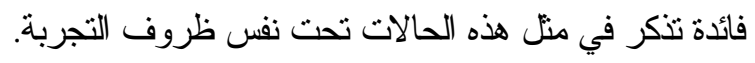

